Chirurgia (2019) 114: 798-808

No. 6, November - December Copyright $\odot$ Celsius

http://dx.doi.org/10.21614/chirurgia.114.6.798

\title{
Roux-en-Y Feeding Jejunostomy - The Preferred Surgical Option for Enteral Nutrition in Patients with Leaks or Fistula after Gastric Sleeve
}

\author{
Catalin Copaescu ${ }^{1,2}$, Bogdan Smeu', Mani Habibi ${ }^{3}$ \\ ${ }^{1}$ Ponderas Academic Hospital Bucharest, Romania \\ 2"Grigore T Popa" University of Medicine and Pharmacy, Iasi, Romania \\ ${ }^{3}$ Lara Anatolia Hospital, Antalya, Turkey
}

Corresponding author: Catalin Copaescu, MD PhD Associated Professor of Surgery Ponderas Academic Hospital Nicolae Caramfil Street, no. 85 A district 1, Bucharest, Romania

E-mail: catalin.copaescu@ponderas-ah.ro

\section{Abbreviations:}

LSG - laparoscopic sleeve gastrectomy;

NJT - naso-jejunal tube;

LFJ - loop feeding jejunostomy;

LRYFJ - laparoscopic Roux-en-Y feeding jejunostomy;

EGD - eso-gastro-duodenoscopy;

EN - enteral nutrition;

FJA - fistulo-jejuno-anastomosis; RYGBP - Roux-en-Y Gastric Bypass; JJA - jejuno-jejunal anastomosis; FJ - feeding jejunostomy.
Received: 07.12 .2019 Accepted: 20.12.2019

\section{Rezumat}

Jejunostomia de alimentație pe ansa în Y a la Roux - opțiunea chirurgicală preferată pentru nutriția enterală la pacienții cu fistule după gastrectomia longitudinală

Background: Fistulele sunt complicații rare după gastric sleeve laparoscopic, însă pot determina o morbiditate semnificativă şi îndelungată. Nutriția enterală este obligatorie pentru vindecarea fistulei sau a dehiscenței liniei de sutură gastrică, iar sonda nasojejunală sau jejunostomia pe ansa continuă au unele limitări şi morbidități asociate. Propunerea noastră alternativă este jejunostomia laparoscopică pe ansa în Y "a la Roux" pentru asigurarea suportului nutrițional pe termen mediu şi lung al pacienților cu fistulă sau dehiscență a liniei de agrafare după gastric sleeve.

Scopul: Investigarea jejunostomiei pe ansa în Y "a la Roux" şi descrierea tehnicii chirurgicale cu evaluarea eficienței şi a rezultatelor acesteia.

Metoda: Timpii chirurgicali ai jejunostomiei laparoscopice pe ansa in Y "a la Roux" sunt descrişi în detaliu cu descrierea dificultăților tehnice care pot fi întâlnite. Pentru implementarea tehnicii jejunostomiei laparoscopice pe ansa in Y "a la Roux" pacienților cu fistule sau dehiscența liniei de agrafare după gastric sleeve cât şi pentru derularea acestui studiu a fost obținută aprobarea Comitetului de Etică al Ponderas Academic Hospital. Toți pacienții la care s-a efectual jejunostomie laparoscopică pe ansa in Y "a la Roux" în centrul nostru, cu începere din 2015, au fost incluşi în acest studiu prospectiv. Au fost analizate 
caracteristicile medicale ale pacienților, dificultățile tehnice ale procedurii şi rezultatele acestora.

Rezultate: Şase pacienți (4 femei şi 2 bărbați, vârsta medie $37.1 \pm 11.5$ ani) cu gastrectomie longitudinală laparoscopică (gastric sleeve) au fost referiți către spitalul nostru după ce drenajul inițial al fistulei a fost efectuat în alte unităti medicale, efectuându-se în centrul nostru jejunostomia laparoscopică pe ansa în Y "a la Roux". Timpul operator mediu a fost de 127.5 \pm 61.2 minute. Durata medie a menținerii jejunostomiei a fost de $183.83 \pm 128.2$ zile. Nu a existat mortalitate asociată. Fistulo-jejunostomia laparoscopică a fost tratamentul definitiv pentru cinci pacienți (83.3\%) în timp ce, la al şaselea pacient fistula s-a vindecat spontan.

Concluzii: Suportul nutrițional adecvat este obligatoriu în tratamentul fistulei după gastric sleeve. Jejunostomia laparoscopică pe ansa în Y "a la Roux" are multe avantaje față de sonda naso-jejunală sau jejunostomia pe ansa continuă, mai ales pentru tratamentul fistulelor gastrice cronicizate. Experiența noastră demonstrează că jejunostomia laparoscopică pe ansa în Y "a la Roux" poate fi implementată în siguranță în varianta tehnică pe care o descriem.

Cuvinte cheie: nutriție enterală, jejunostomia de alimentație pe ansa în Y a la Roux, dehiscența, fistule, gastrectomie longitudinală

\begin{abstract}
Background: Leaks are rare complications of laparoscopic sleeve gastrectomy (LSG) but, they may cause significant and prolonged morbidity. Enteral nutrition is mandatory for the gastric leak or fistula therapy's success and the naso-jejunal tube (NJT) as well the loop feeding jejunostomy (LFJ) have some limitations and morbidities. We propose an alternative, the laparoscopic Roux-en-Y feeding jejunostomy (LRYFJ) to support the mid- and long-term nutritional need of the patients complicated with gastric leaks or fistulas.

Aim: to investigate the laparoscopic Roux-en-Y feeding jejunostomy (LRFJ) and to evaluate the surgical technique, its' efficiency and outcomes.

Methods: The surgical steps of LRFJ are described in detail and the technical challenges are commented. The IRB approval was obtained for performing the LRYFJ in patients with gastric leaks or fistulas after LSG and to run the present study. All the patients who received LRYFJ in our center since 2015 were included into a prospective study. The patient's medical characteristics, as well the procedure's technical challenges and outcomes are analyzed.

Result: Six patients (4 females, 2 males; age $37.1 \pm 11.5$ years) who previously underwent LSG, were referred to our unit after the initial drainage for gastric leak in other institution and, LRYFJ was performed in all. Mean operative time was $127.5 \pm 61.2$ minutes. Mean duration of jejunal nutrition was $183.83 \pm 128.2$ days. No related mortality was encountered. Laparoscopic fistulo-jejunostomy was the definitive fistula treatment in five of the patients $(83.3 \%)$ while in one patient (16.6\%) the leak was spontaneously healed.

Conclusion: Adequate nutritional support is mandatory for the gastric sleeve leak treatment. LRYFJ has many advantages over naso-jejunal tube and loop type feeding jejunostomy particularly in treatments of prolonged sleeve leaks or fistulas. Our experience demonstrates that LRYFJ can be implemented safely with the technique we described.
\end{abstract}

Key words: enteral nutrition, laparoscopic Roux-en-Y feeding jejunostomy, leaks, fistulas, sleeve gastrectomy 


\section{Introduction}

Laparoscopic sleeve gastrectomy (LSG) is the most performed bariatric procedure worldwide (1) and it is known as a safe procedure with a low complication rate. Some of these complications, as the staple line leaks, can cause prolonged morbidity (2). Various treatment options for gastric leaks have been described (1-3). Management of LSG sleeve leaks is difficult and complicated, and treatment options range from nonoperative management and endoscopic stenting to definitive reconstructive operations. Many treatment algorithms depend on the timing of the leak's presentation, the presence of a stricture or peritonitis, and the nutritional status of the patient (4).

In patients with gastric leaks and general peritonitis, the laparoscopic exploration with complete peritoneal lavage and drainage is the option to control the septic damage. Within this stage the parenteral nutrition the procedure of choice as the small bowel is affected by the intraabdominal inflammation. After this faze, as well when the septic collection is contained, or we deal with a gastric fistula (as a chronic status) the enteral nutrition (EN) is a mandatory support for the leak or fistula therapy's success (5).

Among the available options for $\mathrm{EN}$, the naso-jejunal tube (FREKA® TRELUMINA FRESENIUS-KABI) (6) as well the loop jejunostomy $(4,5)$ are efficient but they have certain limitations and morbidities $(7,8)$.

We propose an original modification of the feeding jejunostomy, the laparoscopic Rouxen-Y feeding jejunostomy (LRYFJ) aiming to support mid- and long-term nutritional needs of the patients complicated with gastric leaks or fistulas after LSG. The technique was inspired by the neurological pediatric and adult pathology, for which long-term nutritional support is provided by a similar procedure $(9,10)$. The Roux-en-Y feeding jejunostomy is not only associating less morbidity but, it may provide an easy replacement of the feeding tube $(10,11)$.

The aim of the study is to investigate the laparoscopic Roux-en-Y feeding jejunostomy (LRYFJ) and to evaluate the surgical technique, its' efficiency and outcomes.

\section{Methods}

The IRB approval was obtained for using the laparoscopic Roux-en-Y feeding jejunostomy (LRYFJ) in patients with gastric leaks or fistulas after LSG and to run the present study.

All the patients who received LRYFJ in our Bariatric Center of Excellence since 2015 were included into a prospective study. The patient's medical characteristics, the time from LSG or previous surgeries, technical challenges of the procedure and its' outcomes are analyzed. The excluding criteria address to the patients who, for any reason could not be followed up. An informed consent was signed by all the patients.

All the patients presenting gastric leak or gastric fistula after LSG are resuscitated and, an extended preoperative work-up is applied, in order to complete the medical information. This step of the protocol is mandatory for both patients who underwent the LSG in our hospital or in other institutions, latter being referred to our Centre for the complication's treatment. The multidisciplinary team is to consider the level of emergency and the diagnostic sequence in each case. CT scan of the abdomen and pelvis with oral and intravenous contrast, the upper GI radiological study, and eso-gastro-duodenoscopy (EGD) are part of this protocol.

In patients with gastric leaks and general peritonitis, the laparoscopic exploration with complete peritoneal lavage and drainage is the option to control the septic damage. Within this stage the parenteral nutrition the procedure of choice as the small bowel is affected by the intra-abdominal inflammation. If the septic collection is limited, or we deal with a chronic condition such as gastrocutaneous, gastro-pleural, gastro-bronchial or any other type of gastric fistulas, placing the enteral nutrition ( $\mathrm{EN})$ is a mandatory for the success of the medical therapy. A naso-jejunal tube (NJT) placed by the endoscopist and 
verified radiologically is used for several days to bridge to a longer lasting feeding solution and compensate the patient's nutritional imbalances. The laparoscopic Roux-en-Y feeding jejunostomy (LRYFJ) is considered and scheduled for the next days.

\section{Indications for LRYFJ}

To conclude, the LRYFJ is indicated in two situations of an active gastric leak /fistula after laparoscopic sleeve gastrectomy:

1. The patient had previously a surgical exploration (laparoscopy or laparotomy) for the LSG leak aiming the damage control of the general peritonitis and driving out the eso-gastric secretions. At this stage, the gastric leak flow is still high, several endoscopic and/or CT guided unsuccessful attempts to control the leak may be performed (i.e. stents, pig-tail, clips, glues) while the parenteral nutrition and the NJT are reaching their limits of tolerance. A mid- to long-term nutritional support is further needed to support the healing of the leak. LRYFJ is considered.

2. The patient had no surgical intervention after the LSG, and several endoscopic and/or CT guided therapeutical attempts were addressed to the gastric leak or fistula and failed to close it. LRYFJ is considered.

In both situations the small bowel is expected to be normal, not affected by the peritonitis. The LRYFJ will be easily suspended after the healing of the eso-gastric leak or fistula. However, another surgical procedure such as fistulo-jejuno-anastomosis (FJA) or Roux-en-Y Gastric Bypass (RYGBP) might be needed in the meantime. Thus, choosing the enteral site of the feeding jejunostomy should not affect any future constructions.

\section{Surgical Technique}

LRYFJ is performed under general anesthesia with oro-tracheal intubation and, the patients is placed on the operative table in dorsal decubitus. The surgical steps of LRYFJ, designed to have the enteral access in the left flank, are described below (Fig. 1).

A Veress needle is used for $\mathrm{CO} 2$ insufflation in the left flank. A $10 \mathrm{~mm}$ optical trocar is placed nearby umbilicus, slightly to the right and, under the direct vision of a $10 \mathrm{~mm} 45$ degrees endoscope, two cannulas of $5 \mathrm{~mm}$ are placed in the right and left flank, on medioclavicular line. Another $12 \mathrm{~mm}$ trocar is placed in the hypogastrium, to provide a proper triangulation for stitching the feeding jejunostomy.

Laparoscopic exploration with adequate adhesiolysis is carefully performed, using the two $5 \mathrm{~mm}$ ports. In Trendelenburg position, the ommentum and the transverse colon are placed above the liver and the angle of Treitz is identified. The site of the feeding jejunostomy is decided considering the local anatomy, the presence of adherences, scars or the bowel obstructions and, not to alter the nutrients physiological absorption or any of the future constructions using the enteral loops.

Usually, the jejunum is transected $40-50$ $\mathrm{cm}$ inferior to the angle of Treitz (Fig. 2), with a $60 \mathrm{~mm}$ white cartridge (Fig. 3), after opening the mesentery with an advanced bipolar or ultrasonic energy device. Care should be taken to preserve the vascular supply of both bowel

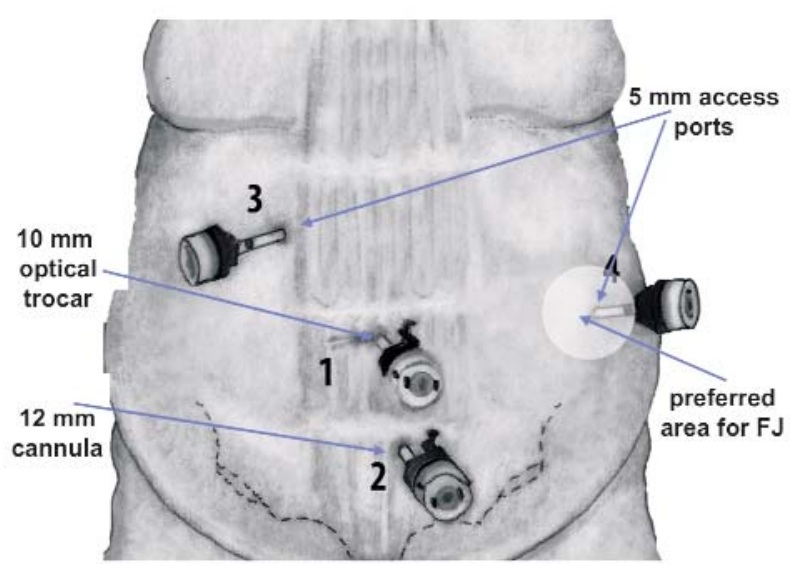

Figure 1. Laparoscopic Roux-en-Y feeding jejunostomy (LRYFJ). Trocars' disposition scheme. The preferred area for feeding Jejunostomy (FJ) is centered by a 5 $\mathrm{mm}$ cannula 


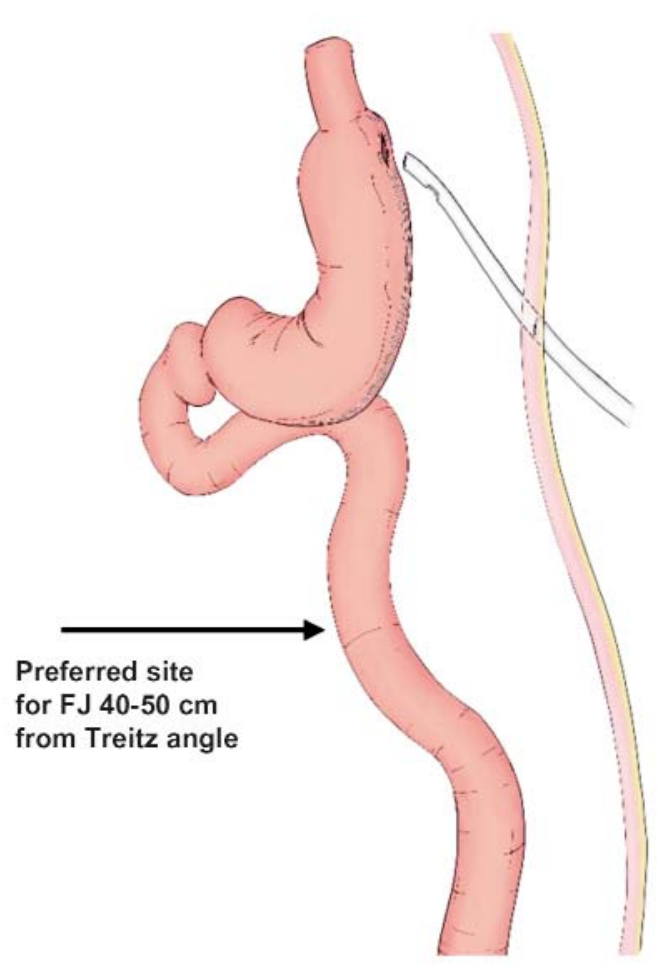

Figure 2. The anatomy before LRYFJ. The LSG leak or fistula is efficiently driven out. The arrow is indicating the site of the feeding jejunostomy and enteral transection

segments. The stapler is introduced through the suprapubic $12 \mathrm{~mm}$ trocar.

The proximal end of the efferent limb will be the site of jejunostomy. A $10 \mathrm{~cm}$ Roux-en-Y limb will be approximated on the efferent limb, to exclusively host the feeding tubes. (Fig. 4). A side-to-side enteral anastomosis will be performed at the Roux-en-Y limb's foot (Fig. 5 A-C) To do this, a stay stitch (PDO 2/0) is used to approximate the proximal and distal loops. This stay-stitch will be passed throughout the anterior abdominal wall in the upper left quadrant using a fascial closure (KarlStorz, Germany), thus hanging up the montage for a better access to the jejuno-jejunal anastomosis (JJA). (Fig. 5 A) This stitch will also mark the proximal part of the JJA. The distal part of the JJA will be marked with another stay stich (PDO 2/0), passed 6-7 cm distal from the first one. This time, a long thread, pulled out through the $12 \mathrm{~mm}$ port will be used and, its' both ends will be grasped by an outside Pean forceps.

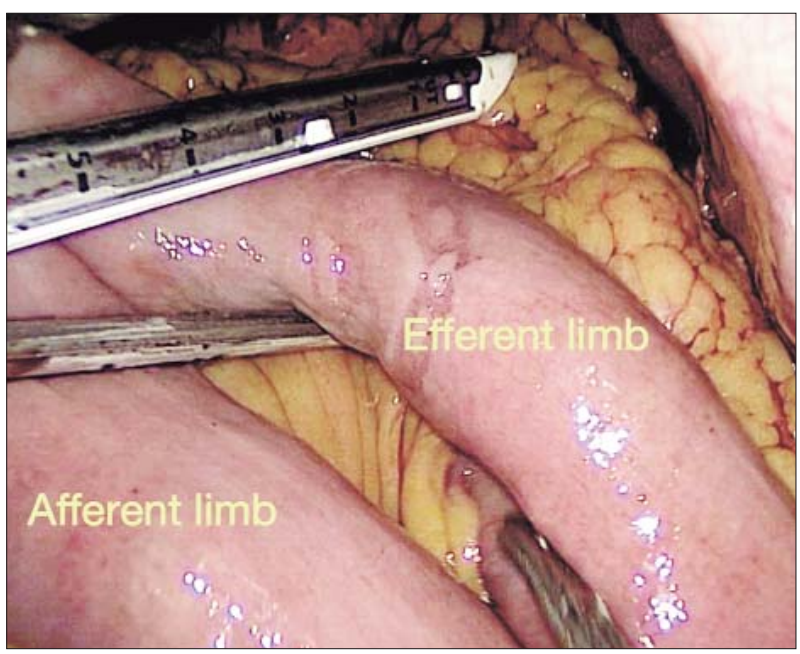

Figure 3. Laparoscopic Roux-en-Y feeding jejunostomy (LRYFJ) - Transecting the jejunal loop with a 2.5/60 mm linear stapler. The afferent and efferent limbs are separated

Using a monopolar hook or an ultrasonic device, small enterotomies are made into both bowel loops, $5 \mathrm{~mm}$ cranially from the distal stay-stitch, on the anti-mesostenic enteral edge. Another $60 \mathrm{~mm}$ linear stapler (white or gold cartridge) is introduced through the

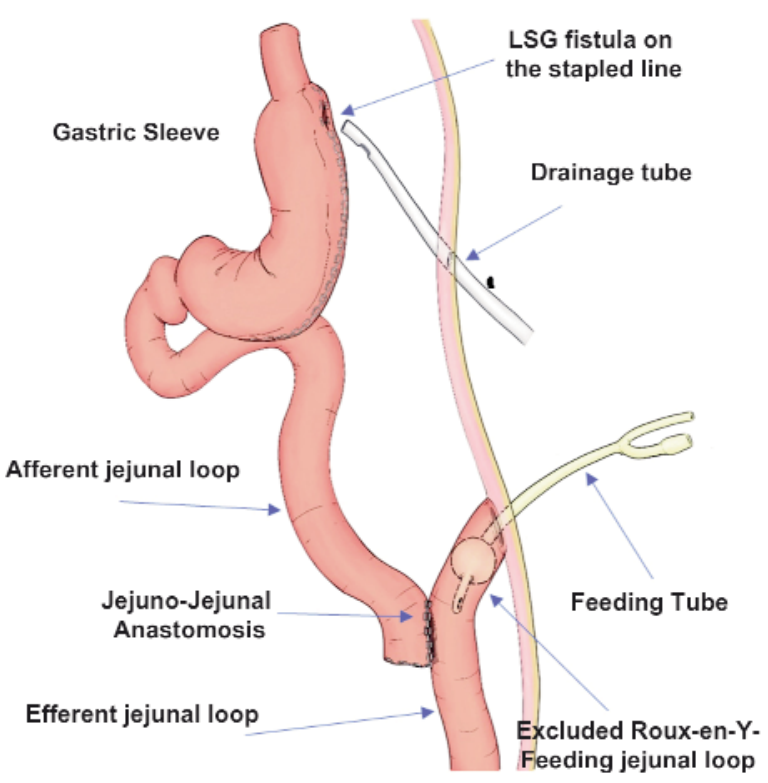

Figure 4. Laparoscopic Roux-en-Y feeding jejunostomy (LRYFJ). - The scheme of the procedure. A short Roux-en-Y limb is excluded and dedicated to the feeding tube 
$12 \mathrm{~mm}$ trocar and, a side-to-side anastomosis is performed (Fig. 5 B).

In order to prevent the intra-luminal bleeding, we always entirely inspect the stapled line while raising the systolic blood pressure (BP) up to $30 \%$ over the patient's preoperative value. If any bleeding is identified, medium-large hemostatic clips are used to control the bleeding sources. The anterior opening is closed with a two-ways running suture (Prolene 3/0) (Fig. 5 C).

The suspension of the initial stay stitch will help us maintain a good view of the anterior aspect of the anastomosis.

After completing the JJA we now concentrate at the jejunostomy site (Fig. $6 \mathrm{~A}-\mathrm{D})$.

We inspect initially the vascularity of the Roux-en-Y limb (Fig. 6 A) and then pass a purse-string suture on the cranial end of the Roux limb, surrounding to the stapled line. We approximate the best position for placing the jejunostomy on the anterior abdominal wall, 4-5 cm caudally from the peri-gastric drainage tubes, in the left flank (Fig. 1). After opening the jejunum inside of the purse-string by using the monopolar hook or ultrasonic shears, a18 Fr Folley catheter is passed through the existing $5 \mathrm{~mm}$ cannula and then inside the Roux limb, and the purse-string is tight to secure its position (Fig. 6 B). We inflate the balloon of the catheter with 8-10 cc of saline and bring the Roux-en-Y limb to the abdominal wall. Under direct vision, the Rouxen-Y limb site is oriented so that, there is no kinking or twisting, and five to six 3/0 PDO sutures are fixating the jejunum, siding the peritoneum, to avoid any abdominal leakage from this site (Fig. 6 C,D).

We always check the final aspect of the limb construction, (Fig 7) the permeability of the catheter, the integrity and the functionality of the JJA with methylene blue before ending the procedure. If the LRYFJ is performed in the described manner, there will be no mesenteric or retro-mesenteric gap to be closed.

\section{Statistical Analysis}

Statistical analysis was performed with SPSS
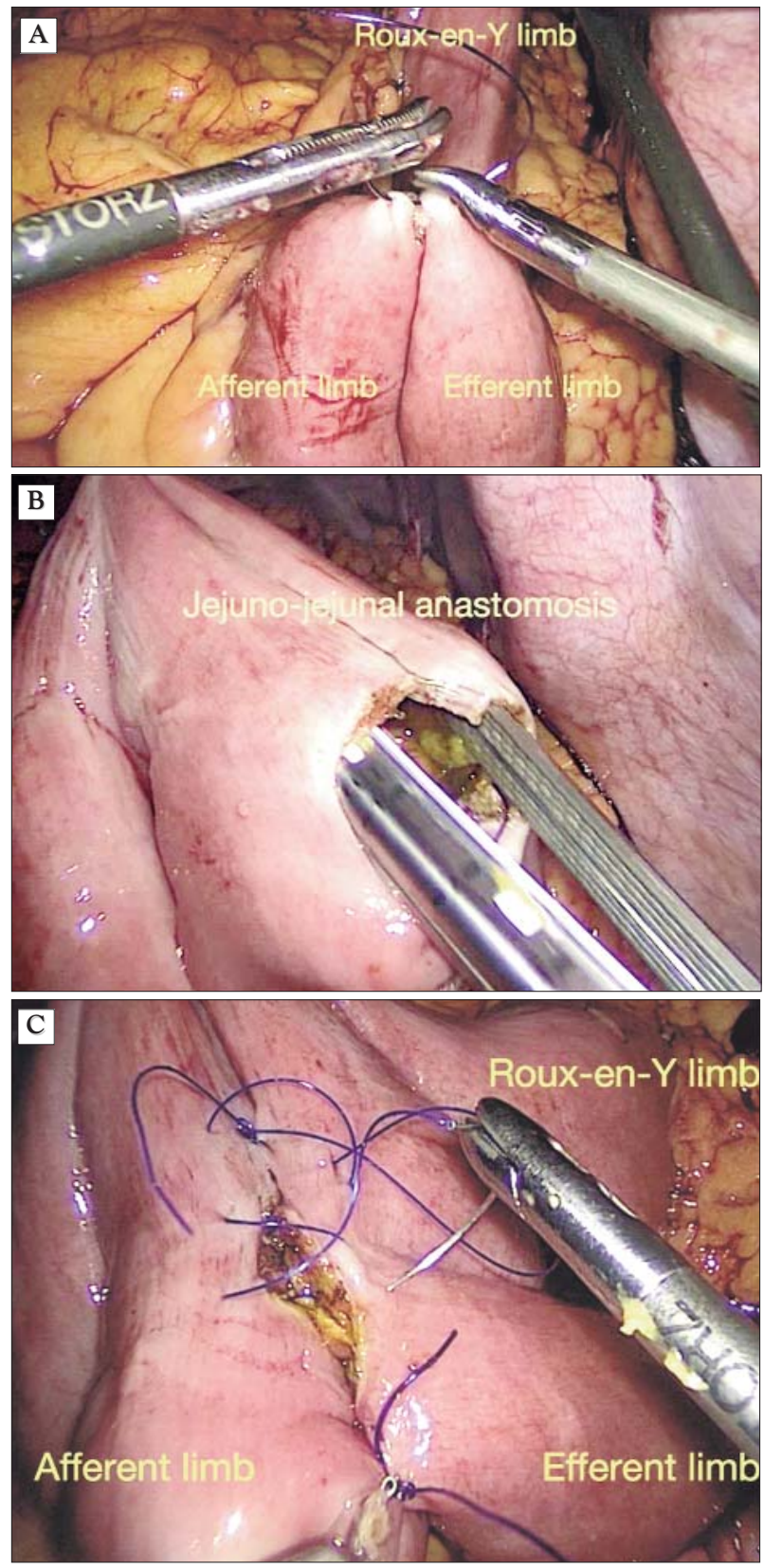

Figure 5. Laparoscopic Roux-en-Y feeding jejunostomy (LRYFJ). Fashioning of the jejuno-jejunal anastomosis (A-C). (A) Approximating the afferent and efferent limbs for the jejuno-jejunal anastomosis. The excluded limb (Roux-en-Y) can be seen above the efferent limb; (B) The jejuno-jejunal anastomosis after firing the linear stapler. The anterior opening can be seen before retracting the stapler; (C) Closing the anterior opening of the jejuno-jejunal anastomosis with running suture (Prolene $3 / 0$ )

version 22 (Chicago, IL, USA), and the level of significance was set at $p \leq 0.05$. Categorical data were reported as frequencies and 

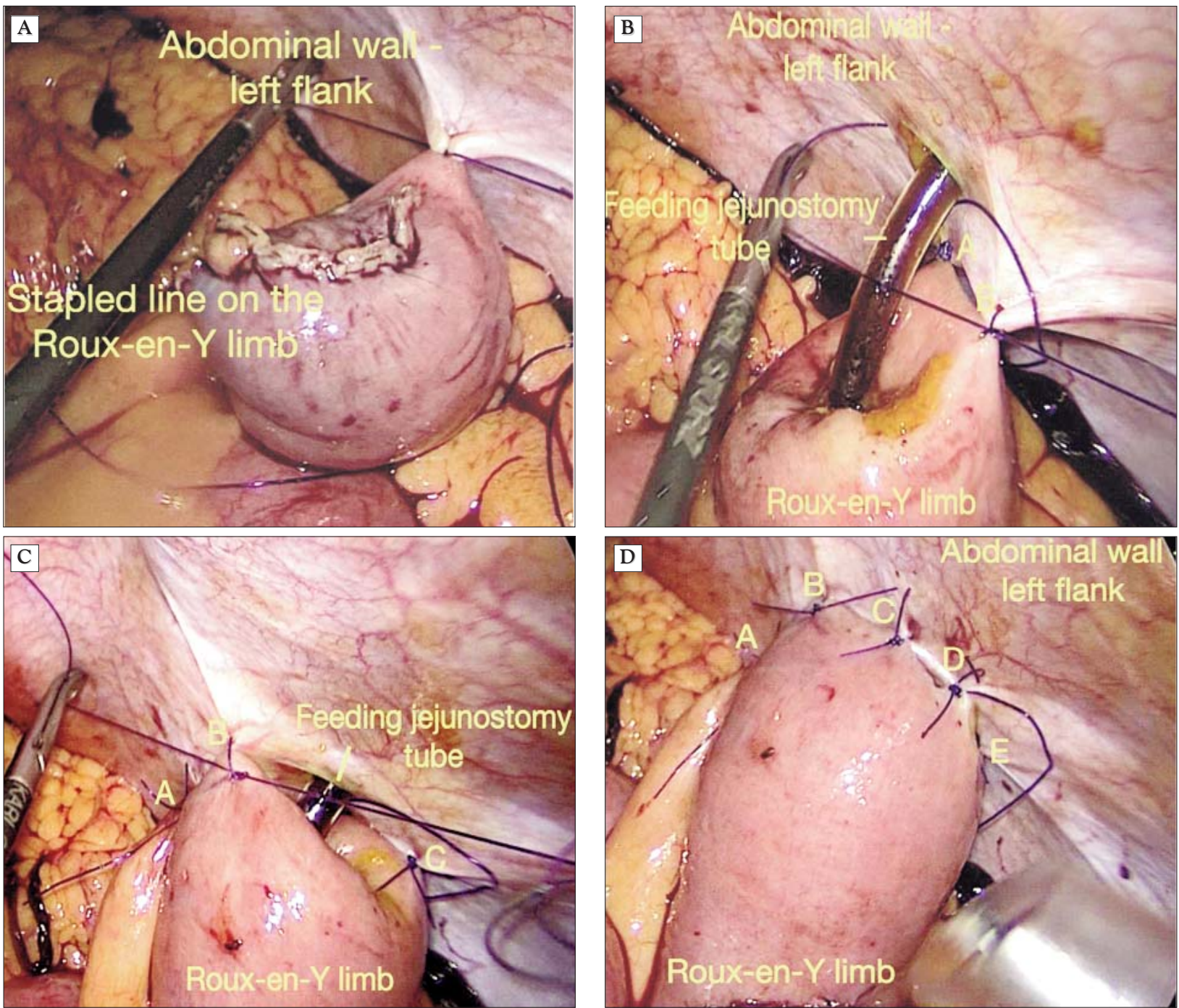

Figure 6. Laparoscopic Roux-en-Y feeding jejunostomy (LRYFJ). Insertion and fixation of the feeding tube (A-D). (A) Fixation the RouX-en-Y limb to the abdominal wall in the left flank with the first suture. The stapled line of the Roux-en-Y limb can be seen; (B) The feeding jejunostomy tube is inserted through the abdominal wall into the Roux-en-Y limb and the purse-string suture is tight around the tube. The first two fixation points ( $A$ and $B$ ) of the Roux-en-Y limb to the abdominal wall in the left flank are part of a circular line of fixation; (C) Feeding jejunostomy tube is gradually isolated with multiple fixation points (A, B and C) to the abdominal wall in the left flank; (D) The final aspect of the jejunostomy (view from medial). The feeding tube completely isolated with multiple fixation points ( $A, B, C, D$ and $E)$.

percentages and continuous data as average (mean) and standard deviation.

\section{Results}

Six patients (four females, two males; age 37.1 \pm 11.5 years) who previously underwent LSG received LRYFJ in our hospital. No patient was lost for follow-up.

None of the patients had the sleeve resection in our Bariatric Center. They were referred to our unit after an initial drainage for gastric leak complication.

LSG was performed as a revision surgery in two patients (one after gastric banding, one after gastric plication). Two patients needed LRYFJ because they could not tolerate a naso-jejunal tube, one patient had severe dysphagia, and three patients were predicted to need long term nutritional support. 


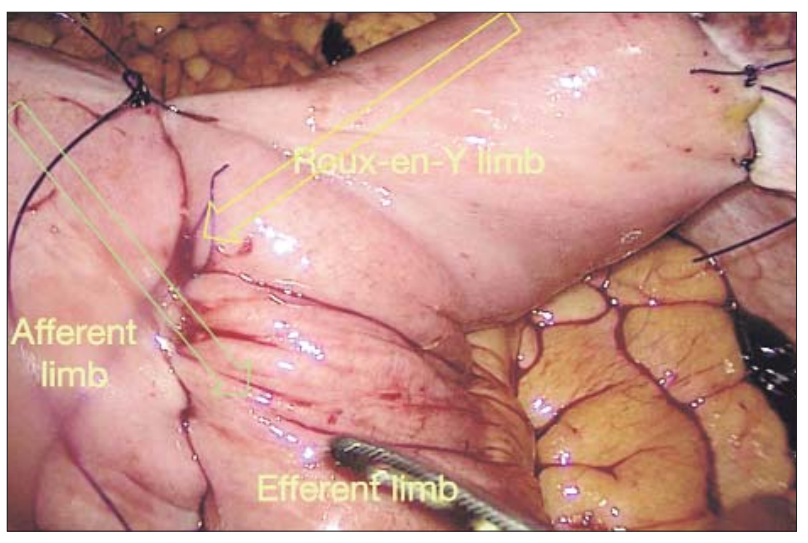

Figure 7. Laparoscopic Roux-en-Y feeding jejunostomy (LRYFJ). The final aspect. The afferent, efferent, excluded limbs (Roux-en-Y) and the jejuno-jejunal anastomosis can be observed in a functional position. The green arrow is demonstrating the biliopancreatic flow; the yellow arrow is showing the food flow coming from the excluded Roux-en-Y limb

The time between the gastric sleeve and the LRYFJ procedures was $27.8 \pm 10.5$ days.

All the procedures were finalized by laparoscopic surgery. The mean operative time was $127.5 \pm 61.2$ minutes. In three $(50 \%)$ operations, laparoscopic adhesiolysis was also performed. Enteral feeding was started postoperatively on the first day following the radiologic control of the passage, as shown in contrast studies.
The mean duration of the jejunal nutrition was $183.83 \pm 128.2$ days. One bleeding complication was observed due to a contact lesion from the jejunostomy tube on the intestinal mucosa; this complication was managed by endoscopic hemostasis. Five (83.3\%) of the patients with LRYFJ required a fistulojejunostomy to complete their treatment, while in one (16.6\%) patient, the leak was spontaneously healed. A complete summary of the LRYFJ patients is provided in Table 1.

\section{Discussion}

Early oral feeding is the preferred mode of nutrition for surgical patients. Moreover, malnutrition is an important risk factor for the poor control of any postoperative complication (12). For patients requiring long-term nutritional support, enteral access has many proven benefits over parenteral access, including improved immune response, preserved gastrointestinal mucosal integrity, and reduced septic complications (13). In addition, enteral nutrition prevents the risk associated with central venous catheter infection (13).

When managing a gastric sleeve leak, in which the patient will need a longer recovery time, it is essential to physiologically maintain

Table 1. Patients with Laparoscopic Roux-en-Y Feeding Jejunostomy (LRYFJ). Demographics and outcomes

\begin{tabular}{|c|c|c|c|c|c|c|c|c|}
\hline $\begin{array}{c}\text { Case } \\
\text { no }\end{array}$ & Age & Sex & $\begin{array}{l}\text { Duration Between } \\
\text { LSG to LRFJ } \\
\text { (day) }\end{array}$ & $\begin{array}{l}\text { Operation } \\
\text { time (min) }\end{array}$ & $\begin{array}{l}\text { Concomitant } \\
\text { surgery }\end{array}$ & Complication & $\begin{array}{l}\text { Duration of } \\
\text { Jejunostomy } \\
\text { (day) }\end{array}$ & $\begin{array}{c}\text { End } \\
\text { Procedure }\end{array}$ \\
\hline 1 & 38 & $\mathrm{~m}$ & 27 & 240 & $\begin{array}{l}\text { Lavage, drainage, } \\
\text { adhesiolysis }\end{array}$ & - & 84 & $\begin{array}{c}\text { Laparoscopic } \\
\text { fistulojejunostomy }\end{array}$ \\
\hline 2 & 38 & $\mathrm{~m}$ & 32 & 90 & - & - & 220 & $\begin{array}{c}\text { Laparoscopic } \\
\text { fistulojejunostomy }\end{array}$ \\
\hline 3 & 36 & $f$ & 23 & 75 & & $\begin{array}{l}\text { - bleeding - contact } \\
\text { lesion of the } \\
\text { jejunostomy tube on } \\
\text { the intestinal mucosa } \\
\text { (endoscopic haemostasis) }\end{array}$ & 217 & $\begin{array}{c}\text { Spontaneous } \\
\text { healing of leakage }\end{array}$ \\
\hline 4 & 28 & $f$ & 40 & 150 & - & - & 412 & $\begin{array}{c}\text { Laparoscopic } \\
\text { fistulojejunostomy }\end{array}$ \\
\hline 5 & 58 & $f$ & 10 & 120 & adhesiolisys & - & 73 & $\begin{array}{c}\text { Laparoscopic } \\
\text { fistulojejunostomy }\end{array}$ \\
\hline 6 & 25 & $f$ & 35 & 90 & adhesiolisys & - & 109 & $\begin{array}{l}\text { Laparoscopic } \\
\text { fistulojejunostomy }\end{array}$ \\
\hline
\end{tabular}


the patient's nutritional status, through the enteral route. The naso-jejunal tubes (NJT) FREKA® TRELUMINA FRESENIUS-KABI) and feeding jejunostomy (FJ) are the two primary methods of achieving enteral access for patients with gastric sleeve leaks $(4,6)$.

The loop feeding jejunostomy offers several advantages over the NJT $(4,5)$. The NJT can be easily clogged and are hard to be kept in place for many weeks, forcing the limits of any compliant LSG patient. Here are some considerations about the comparisons of the two procedures:

The healing time for leaks will be drastically decreased if enteric feeding is used (14). It is well-known that, the nutrition should be properly managed during the weight loss. This task is even more important in the patients who developed leaks after sleeve gastrectomy, as they rapidly lose proteins, vitamins and minerals vital for a good quality healing. Bashah et al. noted in their study after treating over 73 patients with LSG leaks that the time of healing was up to $66 \%$ longer in patients without enteral feeding. Patients on jejunal feeding had shorter resolution time ( $\mathrm{HR}=2.7, \mathrm{P}=0.018)$, while patients on total parenteral nutrition and post-endoscopic dilatation had $66 \%$ and $50 \%$ increases in the resolution time. This is a very important information, because when we take in consideration months of morbidity, a $66 \%$ increase in time of healing can be quite significant (14)

The naso-enteric feeding tube is often clogged with high density food and may often be complicated by dislodgement, as it has a reported complication rate of $16-36 \%$ (15).

The NJT may cause significant discomfort to the patients, whom tolerance is altered making them to pull out the tube, lowering their compliance to the treatment.

Compared to jejunostomy, NJT are associated with more nausea and vomiting (15). Moreover, the socio-cultural life seems to be more affected in the patients with NJT vs. FJ (16).

On the other hand, the presence of the trans-gastric feeding tube will produce continuous irritation at the leak site impairing the healing of the fistula.

However, placing endoscopically the pigtail drains inside the leak will make possible the early suppressing of the drainage tubes, making sure that the lower atmospheric pressure will not apply continuous suction that will keep the leak open. The higher intraperitoneal pressure will gradually close the abscess walls, directing the content through the gastric tube (6).

Loop jejunostomies and various modifications are the most frequently applied methods of inserting a jejunostomy feeding tube (17). Laparoscopic loop feeding jejunostomy was introduced in 1990 by O'Regan et al. (18)and, it has become a well-established technique $(13,17,19)$. The Roux-en-Y jejunostomy was first described by Mayld (20), and latter considered very useful for neurological pediatric and adult pathology, in which long time nutritional support is needed $(9,10)$. Neuman et al. introduced the first laparoscopic RYFJ in a pediatric population in 2005 (16).

LRYFJ offers several advantages over loop jejunostomy (16).

- Reduced enteral or food leakage at the jejunostomy site;

- Easy replacement of the feeding tube, $(10,11)$ while in loop jejunostomies there are difficulties associated with reintubation of the jejunostomy tube after dislodgment (16).

- The LRYFJ procedure does not require folding of the jejunal wall to create a Witzel tunnel, so there is no potential risk of narrowing of bowel lumen with LRYFJ (16). We generally already observe a narrowed intestinal lumen in patients after gastric sleeve leak, due to the inflammation of the jejunal wall secondary to the peritonitis. Additional narrowing of the lumen by the loop jejunostomy may lead to increased upper pressure into the gastric tube and, to regurgitation of intestinal content that may result in prolonging or failure of fistula closure. For patient with gastric sleeve leaks or fistulas, bile reflux is an undesired 
situation that may prevent closure of the fistula.

- Many sleeve leaks fail to be healed by conservative treatment and need reconstructive surgeries like Roux-en-Y fistulo-jejunostomy (21). The RYFJ may be left in place and another Roux-en-Y loop will be brought up to the gastric fistula origin site. When the healing process is completed at the leak site, the RYFJ will be suspended by a simple extraction of the tube.

Beside these benefits, several drawbacks may limit the extension of the procedure for bariatric surgery and, in particular for gastric sleeve complications. The first one is the complexity of the procedure, consisting in limb construction by stapling devices and suturing. The second one is related to the additional costs of the stapling devices.

However, in this patient group of complicated LSG, we should offer the best treatment available in order to shorten their morbidity and discomfort.

To our knowledge, no studies or publications considered the laparoscopic Roux-en-Y Feeding Jejunostomy as an option to support mid- and long-term nutritional need of the obese or non-obese patients with difficult to treat gastric leaks or fistulas. Our prospective study demonstrated the medical benefits of a very well tolerated and managed enteral feeding solution. The small sample size of our single center study represents a certain limit. Further studies are required to confirm our results.

\section{Conclusion}

The sine qua non for the gastric sleeve leak treatment is adequate and appropriate nutritional support.

The laparoscopic Roux-enY Feeding Jejunostomy LRYFJ is recommended in patients with gastric sleeve leaks or fistulas for whom a mid- and long-term nutritional support is needed.

LRYFJ has many advantages over nasojejunal tube and loop feeding jejunostomy particularly in treatments of sleeve leaks.

Our experience demonstrates that LRYFJ can be safely implemented with the described technique.

\section{Acknowledgement}

The drawings are performed may Filip Mihnea Copaescu.

\section{Conflict of Interest}

The authors declare no conflicts of interests.

\section{References}

1. Shoar S, Poliakin L, Khorgami Z, Rubenstein R, El-Matbouly M, Levin JL, et al. Efficacy and Safety of the Over-the-Scope Clip (OTSC) System in the Management of Leak and Fistula After Laparoscopic Sleeve Gastrectomy: a Systematic Review. Obes Surg. 2017;27(9):2410-8.

2. Aburajab MA, Max JB, Ona MA, Gupta K, Burch M, Michael Feiz F, et al. Covered Esophageal Stenting Is Effective for Symptomatic Gastric Lumen Narrowing and Related Complications Following Laparoscopic Sleeve Gastrectomy. Dig Dis Sci. 2017;62(11):307783.

3. Nedelcu M, Manos T, Cotirlet A, Noel P, Gagner M. Outcome of leaks after sleeve gastrectomy based on a new algorithm adressing leak size and gastric stenosis. Obes Surg. 2015;25(3):559-63.

4. Nimeri A, Ibrahim M, Maasher A, Al Hadad M. Management Algorithm for Leaks Following Laparoscopic Sleeve Gastrectomy. Obes Surg. 2016;26(1):21-5.

5. Iannelli A, Treacy P, Sebastianelli L, Schiavo L, Martini F. Perioperative complications of sleeve gastrectomy: Review of the literature. J Minim Access Surg. 2019;15 (1):1-7.

6. Donatelli G, Ferretti S, Vergeau BM, Dhumane P, Dumont JL, Derhy $S$, et al. Endoscopic Internal Drainage with Enteral Nutrition (EDEN) for treatment of leaks following sleeve gastrectomy. Obes Surg. 2014;24(8):1400-7.

7. Strong AT, Fayazzadeh H, Sharma G, El-Hayek K, Kroh M, Rodriguez J. Feeding the gut after revisional bariatric surgery: The fate of 126 enteral access tubes. Surg Obes Relat Dis. 2018;14(7):986-91.

8. McCann C, Cullis PS, McCabe AJ, Munro FD. Major complications of jejunal feeding in children. J Pediatr Surg. 2019;54(2):258-62.

9. Matino JJ. Feeding jejunostomy in patients with neurologic disorders. Arch Surg. 1981;116(2):169-71.

10. Denis R, Lucas CE, Grabow D, Darmody WR, Ledgerwood AM. Role of Roux-en-Y feeding jejunostomy for patients with acute head injury. Am Surg. 1983;49(6):301-3.

11. Godbole P, Margabanthu G, Crabbe DC, Thomas A, Puntis JW, Abel $G$, et al. Limitations and uses of gastrojejunal feeding tubes. Arch Dis Child. 2002;86(2):134-7.

12. Weimann A, Braga M, Carli F, Higashiguchi T, Hubner M, Klek S, et al. ESPEN guideline: Clinical nutrition in surgery. Clin Nutr. 2017;36(3):623-50.

13. Young MT, Troung H, Gebhart A, Shih A, Nguyen NT. Outcomes of laparoscopic feeding jejunostomy tube placement in 299 patients. Surg Endosc. 2016;30(1):126-31.

14. Bashah M, Khidir N, El-Matbouly M. Management of leak after 
sleeve gastrectomy: outcomes of 73 cases, treatment algorithm and predictors of resolution. Obesity Surgery. 2019.

15. Wang L, Tian Z, Liu Y. Nasoenteric tube versus jejunostomy for enteral nutrition feeding following major upper gastrointestinal operations: a meta-analysis. Asia Pac J Clin Nutr. 2017;26(1):20-6.

16. Neuman HB, Phillips JD. Laparoscopic Roux-en-Y feeding jejunostomy: a new minimally invasive surgical procedure for permanent feeding access in children with gastric dysfunction. J Laparoendosc Adv Surg Tech A. 2005;15(1):71-4.

17. Speer EA, Chow SC, Dunst CM, Shada AL, Halpin V, Reavis KM, et al. Clinical Burden of Laparoscopic Feeding Jejunostomy Tubes. J
Gastrointest Surg. 2016;20(5):970-5.

18. O'Regan PJ, Scarrow GD. Laparoscopic jejunostomy. Endoscopy. 1990;22(1):39-40.

19. Han-Geurts IJ, Lim A, Stijnen T, Bonjer HJ. Laparoscopic feeding jejunostomy: a systematic review. Surg Endosc. 2005;19(7):951-7.

20. Brintnall ES, Daum K, Womack NA. Maydi jejunostomy; technical and metabolic considerations. AMA Arch Surg. 1952;65(3):367-72.

21. Chouillard E, Chahine E, Schoucair N, Younan A, Jarallah MA, Fajardy $A$, et al. Roux-En-Y Fistulo-Jejunostomy as a salvage procedure in patients with post-sleeve gastrectomy fistula. Surg Endosc. 2014;28(6):1954-60. 